Transport and Communications Science Journal

\title{
EVALUATION ON THE ADOPTION OF TRANSPORTATION E-MARKETPLACE IN VIETNAM FROM THE DEMAND SIDE' VIEWPOINT
}

\author{
Pham Xuan Dung ${ }^{1}$, Hoang Huong Giang ${ }^{2}$, Nguyen Thi Van Ha*3 \\ ${ }^{1}$ University of Foreign Trade, Chua Lang, Lang Thuong, Hanoi, Vietnam \\ ${ }^{2}$ Hanoi Metropolitan University, No 96 Duong Quang Ham Street, Hanoi, Vietnam \\ ${ }^{3}$ University of Transport and Communications, No 3 Cau Giay Street, Hanoi, Vietnam \\ ARTICLE INFO
}

TYPE: Research Article

Received: 05/10/2020

Revised: 20/12/2020

Accepted: 23/12/2020

Published online: 27/05/2021

https://doi.org/10.47869/tcsj.72.4.4

*Corresponding author

Email: nguyenha@utc.edu.vn; Tel: 0936062526

\begin{abstract}
Studying on transportation e-marketplaces (TEMs) has today received much concern because developing TEMs helps enterprises and their customers reduce operation costs and improve supply chain efficiency. This study evaluates the adoption of TEMs in Vietnam based on the demand side's perspective, including the viewpoint of shippers and the Transport Service Providers (TSPs). While shippers and TSPs around the world are facing various issues related to transportation and logistics process in the competitive market, TEMs is a potential solution which can offer response to those challenges such as transaction cost reduction, better transport capability, inefficiency diminishment, ... In Vietnam, TEMs is still a new concept with the limitation of usage, so that the number of researches on this topic is scarce. This study followed the quantitative research method via SPSS technique of data analysis to provide a brief view of TEMs adoption in Vietnam. These insights can make contribution to both research and practice in the future.
\end{abstract}

Keywords: Transportation e-marketplace (TEM), Transportation, Logistics, Shipper, Transport Service Providers (TSPs)

(C) 2021 University of Transport and Communications

\section{INTRODUCTION}

Transportation plays an important role in not only logistics but also supply chain while it 
refers to "the movement of product from one location to another as it makes its way from the beginning of a supply chain to the customer" [1]. Based on the previous definition, transportation can be seen as a bridge between shippers and customers. Transportation services provided must meet requirements imposed on both ends of the link and adapt to the type of products being carried, the legislation tied to those products, the distance to be covered, and the real estate constraints for loading and unloading.

For the last ten years, information and communication technology (ICT) has been utilized in logistics and supply chain at a simple level, for example typing, emailing, printing, scanning documents. Currently, with the appearance of industry revolution 4.0 such as internet of things, block chain, artificial intelligence, ICT has played an important role in almost all stages of logistics and supply chain process. High technologies in industry 4.0 era, such as digitalization, web-based cloud computing, enterprise resource planning (ERP) systems, electronic data interchange (EDI), radio frequency identification (RFID), global positioning system (GPS) and so on have been adopted in global industries for various purposes, including reducing operation costs, facilitating trade and information exchange and then allowing easier negotiations and transactions with shippers and customers $[2,3]$.

Along with the rising of technologies and Internet usage, new business models called electronic marketplace (also known as e-marketplace) appeared in different industries. Emarketplace can be considered to be the place where buyers and sellers of goods or service access to interact and exchange business [4]. In the aspect of transportation, we have transportation e-marketplace or TEM. The main purpose of TEMs is to bridge shippers and transport service providers (TSPs) together to facilitate the flows of goods, services and information.

Around the world, the concept of TEMs is no longer unfamiliar with global researchers in logistics in particular and supply chain in general. There are a lot of researches related to TEMs in various aspect such as the use of TEMs in the perspective of shippers [5] or transport service provider [6]; an evaluation of TEMs in B2B E-commerce [7]; ... In Vietnam, TEMs have been built up to connect shippers and TSPs for the purpose of reducing transport costs and have developed in recent years. However, the number of researches on TEMs is limited, especially related to TEM participation and non-participation. Realizing the gap of research relating TEMs in Vietnam, the authors wrote this article with the aim of deepening the knowledge about TEMs and investigating them from the demand side (shippers, TSPs) to give an overall picture of TEMs in Vietnam.

The article is organized 5 sections. Section 2 shows a brief review of transportation emarketplace (TEM), parties in a TEM as well as factors affecting the adoption of transportation e-marketplace. Section 3 describes the method used for this paper, and Section 4 presents the findings and propositions. The final part is Section 5 which makes the conclusion.

\section{LITERATURE REVIEW}

\subsection{Transportation E-marketplace (TEM)}

The term e-marketplace owns a large number of definitions given by researchers around the world. E-commerce platforms are described as an inter-organization information system that allows participants (sellers and buyers) to exchange information about prices and offers $[8,9]$ or a market. digital for buying and selling goods and services [10]. The rapid development of ICT and related e-commerce applications are important factors contributing 
to the development of intersections. new information translation (infomediaries) in the freight industry in charge of operating electronic markets in order to bring greater efficiency and transparency of information for transport businesses [11]. According to Marasco [12], the fundamental role of these markets is to connect multiple carriers and shippers together in a virtual market space and provide software, tools and services to facilitate communication events and transactions between them. These are preliminary views on transport exchanges (TEMs).

By 2018, after combining the definition of an e-commerce platform and the research results of [12, 13], Andres Rios [6] from Lund University gave the definition for transport exchange as an online intermediary platform or environment designed to provide software, tools, and services with the function of establishing and facilitating a sales relationship (usually a triangular relationship between sellers or transportation service providers, buyers or shippers and a third party providing services in charge of providing trading platforms) and trading operations.

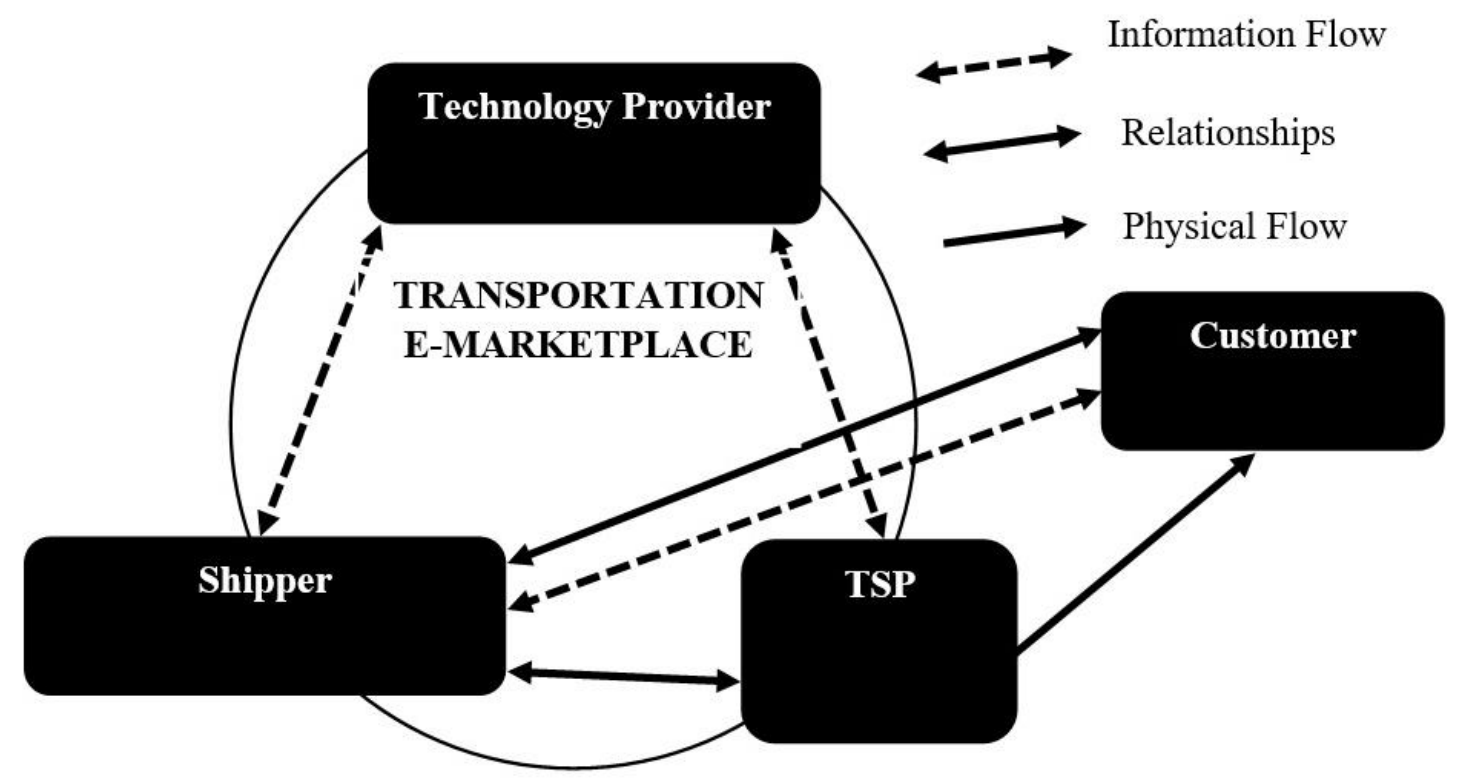

Figure 1. Parties involved in a transportation e-marketplace (Andres Rios [6]).

According to Wang et al. [13], in the logistics industry, a transport exchange is a connection environment of three parties who are transport service buyers (shippers), transport service providers (TSPs) and home technology that is usually a third-party service provider. However, in reality, the service provider can be the shipper itself or the TSP. In some cases, the customer using the goods may also be involved in a transport exchange, but this is not the case. In addition, transport exchange operations are likely to involve other parties such as finance depending on the complexity of the services provided by transport exchanges.

In Vietnam, the freight transport trading platform is still a new concept, not fully completed and has many different understandings. In the article "How does a transport exchange work?" of traffic newspaper, according to Mr. Tran Quang Binh [14], Director of Transport Department (Directorate for Roads of Vietnam), freight trading platform is "e- 
commerce trading platform for transport units. freight, logistics service providers (transport units) and customers wishing to transport goods (shippers) post information about the ability to provide freight and freight services. need to transport and conduct part or the whole process of purchasing and selling freight services".

\subsection{Factors affecting the adoption of transportation e-marketplace}

Numerous studies have argued that e-marketplaces developed evolved from EDI systems and based on e-procurement needs and fully supported by IT (information technology), IS (information system) and communication technologies $[15,16]$. Thus, possible determinants affecting the firm's decision to adopt TEM can be derived from literature regarding: EDI, eprocurement, IT (Information Technology), IS (Information System), communication technologies.

On the basis of prior published research results of Pucihar and Podlogar [17] and suggestions from industry experts, the author has identified three constructs regarding TEM adoption. They are: firm's internal environment (FIE), firm's attitude towards transportation e-marketplaces (FATTEM), and firm's external environment (FEE), denoted as FIE, FATTEM, and FEE, respectively.

The first construct circumscribes "firm's internal environment", which is the demands from the inside of a firm that could push that firm to adopt a TEM and can be measured by 6 indicators as follows: Compatibility for moving current transaction to TEMs [18]; Speed for completing a transaction and exchanging information (based on the IS case given by Thong [19]); level of using IT [20]; Top management support [18, 21, 22]; Employee willingness, knowledge, capability to accept new IT [23, 24]; Seasonality [24].

In the aspect of the relationship between firm's attitude towards TEMs and TEM adoption (Construct 2), there are different researchers studying about factors which can affect this relationship. The authors summarized results of various researches into 6 main group: level of openness [7]), trading mechanism, Potential benefits which the company can gain from using TEM [7, 12, 24, 25, 26]; Cost required for joining a TEM; Level of ease of using interface, functions $[18,21,24]$ and service quality, Security level. The final group was created based on the truth which is that when prices tend to decrease in TEM, the service quality will possibly be affected in negative way and additionally, people also have security concerns related to information sharing, transparency, perceived risk and disclosure of sensitive data.

Firm's external environment is the third construct, which comprises all indicators that come from the outside of the organization and could push it to adopt a TEM. The indicators include trust in current business partners [27, 28], use of information system with business partners, key customers within supply chain or competitors, government support [29] and increase in demand for optimization/cost reduction in transportation.

Based on the mentioned factors, Table 1 below describes three hypotheses and measure indicators authors used for finding differences between TEM adopters and TEM nonadopters. 
Transport and Communications Science Journal, Vol. 72, Issue 4 (05/2021), 437-451

Table 1. Summary of hypotheses and measure indicators for finding the differences between TEM adopters and TEM non-adopters.

\begin{tabular}{|c|c|c|}
\hline No & Hypotheses & Measure indicators \\
\hline H1 & $\begin{array}{l}\text { There is a significant } \\
\text { difference in firm's internal } \\
\text { environment between TEM } \\
\text { adopters and TEM non- } \\
\text { adopters. }\end{array}$ & $\begin{array}{l}\text { - FIE1 - compatibility for moving current } \\
\text { transaction to TEMs; } \\
\text { - FIE2 - speed for completing a transaction and } \\
\text { exchanging information; } \\
\text { - FIE3 - level of using IT; } \\
\text { - FIE4 - top management support; } \\
\text { - FIE5 - employee willingness, knowledge, } \\
\text { capability to accept new IT; and } \\
\text { - FIE6 - seasonality. }\end{array}$ \\
\hline $\mathrm{H} 2$ & $\begin{array}{l}\text { There is a significant } \\
\text { difference in firm's attitude } \\
\text { towards TEMs between } \\
\text { TEM adopters and TEM } \\
\text { non-adopters. }\end{array}$ & $\begin{array}{l}\text { - FATTEM1 - level of openness; } \\
\text { - FATTEM2 - trading mechanism; } \\
\text { - FATTEM3 - potential benefits which the } \\
\text { company can gain from using TEM; } \\
\text { - FATTEM4 - cost required for joining a TEM; } \\
\text { - FATTEM5 - level of ease of using interface, } \\
\text { functions; and } \\
\text { - FATTEM6 - service quality and security level. }\end{array}$ \\
\hline $\mathrm{H} 3$ & $\begin{array}{l}\text { There is a significant } \\
\text { difference in firm's external } \\
\text { environment between TEM } \\
\text { adopters and TEM non- } \\
\text { adopters. }\end{array}$ & $\begin{array}{l}\text { - FEE1 - trust in current business partners; } \\
\text { - FEE2 - use of information system with business } \\
\text { partners; } \\
\text { - FEE3 - key customers within supply chain or } \\
\text { competitors; } \\
\text { - FFE4 - government support; } \\
\text { - FEE5 - increase in demand for optimization/cost } \\
\text { reduction. }\end{array}$ \\
\hline
\end{tabular}

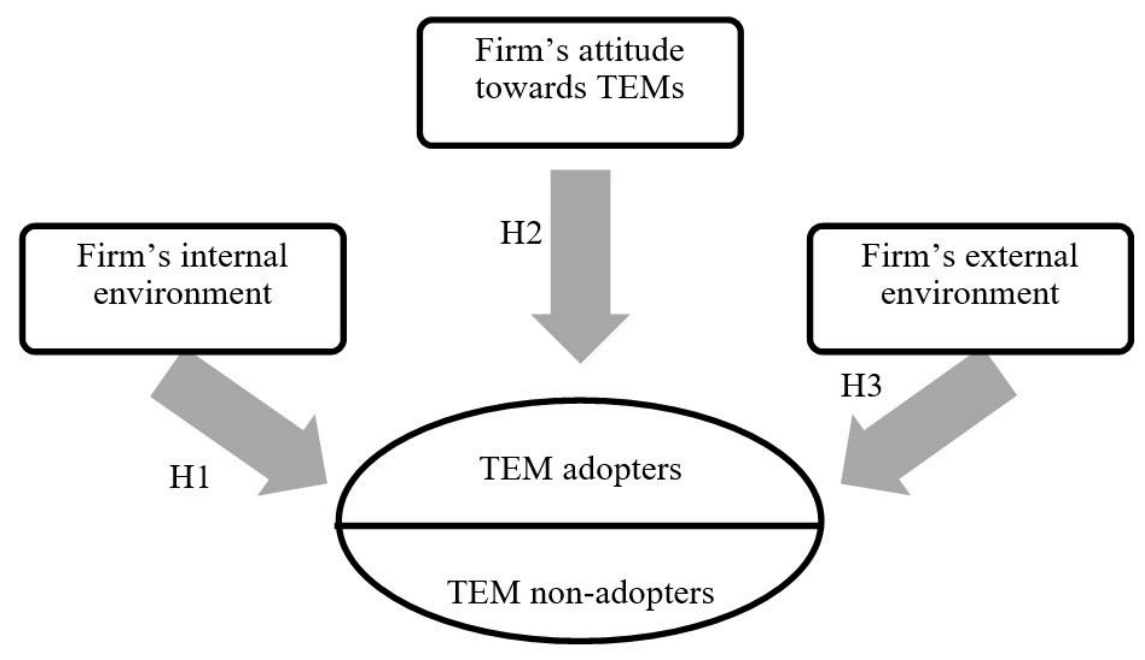

Figure 2. Research model for finding differences between TEM adopters and TEM non-adopters. 
The authors described three hypotheses in the research model in Fig. 2. Research model include 3 constructs related to factors affecting the adoption of TEM adopters and non-TEM adopters for joining transport e-market.

\section{RESEARCH METHODOLOGY}

The authors choose a quantitative research strategy for this paper. The characteristics of quantitative research method are (1) applying techniques of data analysis and data collection that uses or produces numeral data [30] and (2) answering what and how questions [31]. In this case, quantitative research method is suitable for reasons: (1) the purpose of this paper is to evaluate the adoption of Transportation e-marketplaces (TEMs) based on criteria selected by the authors and (2) the data collected is numeric data that need the support of quantitative method. Questionnaire is considered as the main technique of data collection, which can provide large amounts of information from a large number of participants in a short period of time [32].

$\mathrm{Fu}$ et al (2006) shows that the concept of TEM participant is considered to include shippers, carriers and logistics service providers and shippers might be large manufacturers, retailers, distributors or even express companies and so on [33]. Besides, it is undeniable that shippers can exist in a variety of industries such as steel industry, information industry, heavy electrical machinery industry, automobile industry,...In this study, the authors sent questionnaires to 1000 firms in Vietnam via email and tried to balance the number of participants as shippers and TSPs, as well as number of participants in each industry. For the shippers and TSPs in this study, the authors based on the type of industries, and the size of companies to select for sending questionnaires. Most of companies selected are mediumsized companies for shippers and TSPs. Out of 1000 firms, 122 responses were returned. All of the responses are accepted to be valid responses for data analysis.

Table 2. Statistics of survey results.

\begin{tabular}{|l|c|c|}
\hline \multicolumn{1}{|c|}{ number of } & Number of quantities & Percentage (\%) \\
\hline $\begin{array}{l}\text { questionnaires sent } \\
\text { Total number of responses } \\
\text { received }\end{array}$ & 1000 & $100 \%$ \\
\hline $\begin{array}{l}\text { Total number of valid } \\
\text { responses }\end{array}$ & 122 & $12.2 \%$ \\
\hline
\end{tabular}

(Source: Data from the authors)

The valid data will be tested with SPSS (Statistical Package for the Social Sciences). The authors used SPSS 20 to analyze data through four steps: reliability test with Cronbach's alpha, factor analysis, independent t-test and descriptive analysis.

Table 3. Reliability Statistics based on Cronbach's Alpha.

\begin{tabular}{|l|c|c|}
\hline & Cronbach's Alpha & N of Items \\
\hline Firm's internal environment & 0.848 & 6 \\
\hline Firm's attitude towards TEM & 0.867 & 6 \\
\hline Firm's external environment & 0.767 & 5 \\
\hline
\end{tabular}

(Source: Data from the authors) 
For reliability test, the Cronbach's Alpha value of Firm's internal environment (FIE), Firm's attitude towards TEM (FATTEM) and Firm's external environment (FEE) are respectively $0.848,0.867,0.767$, which are greater than 0.6 and satisfy the test. As a result, factors of those scale are acceptable and will be analyzed in the next step. After conducting factor analysis, the total scale comprises of 17 variables which have the acceptable level of convergence along with components. All observable variables will be divided into 3 components, namely firm's internal environment (FIE), Firm's attitude towards transportation e-marketplaces (FATTEM) and Firm's external environment (FEE).

\section{FINDINGS AND DISCUSSIONS}

First of all, the authors will give a brief description summary of 122 samples in this study.

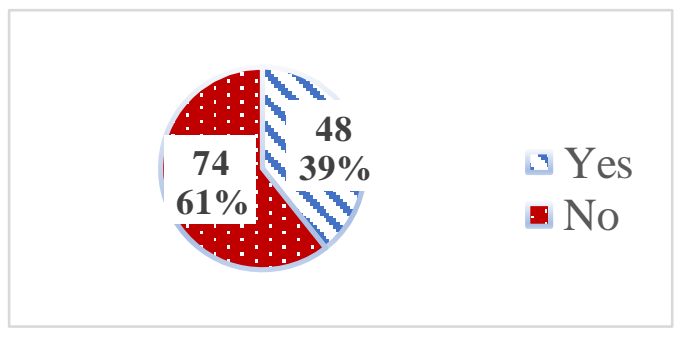

Figure 3. TEM adoption distribution.

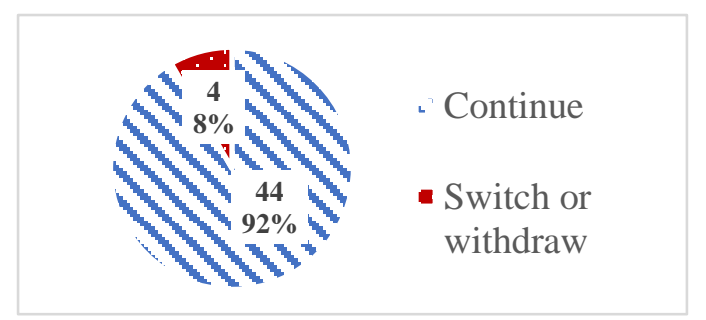

Figure 4. Continue to use TEM or not distribution.

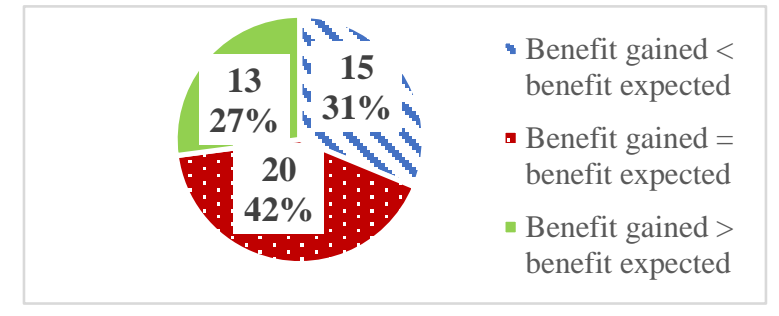

Figure 5. Benefit gained and benefit expected comparison distribution.

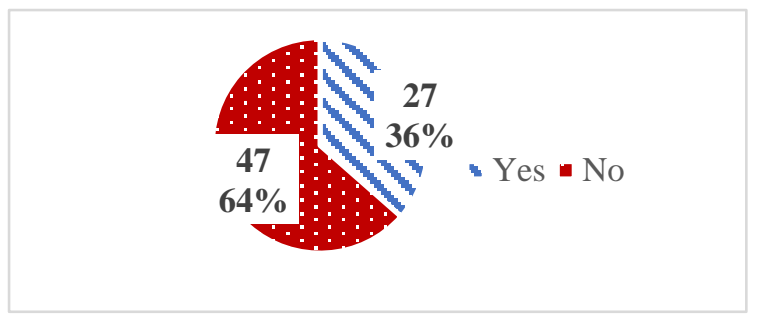

Figure 6. Plan to adopt TEM or not distribution.

According to Fig. 3 above, among 122 valid responses, interestingly, 48 firms have used TEM, which accounts for $39.3 \%$, while the other 74 firms have not used any TEM, comprising $60.7 \%$ of the samples. Fig. 4 shows that 4 out of 48 firms that have adopted TEM will switch or withdraw from the current TEM, representing $8.3 \%$ of the adopted TEM firms. Meanwhile, the other 44 firms will continue to use the current TEM, which is $91.7 \%$ of the adopted TEM firms. It can be clearly seen from Fig. 5 that $27 \%$ of firms utilizing TEMs gained more benefit than expected, whereas $31.3 \%$ of these firms answered "Benefit gained $<$ benefit expected", and $41.7 \%$ answered "Benefit gained = benefit expected". For 74 firms that haven't used any TEM, 47 firms answered no to the question of them planning to adopt within 1 year or not, which accounts for $63.5 \%$, while the other 27 firms have plan to adopt TEM within 1 year (see Fig. 6).

From the received results from SPSS method, for all sampled firms, firm's internal environment, firm's attitude towards transportation e-marketplaces, and firm's external environment are different between TEM adopters and TEM non-adopters. Therefore, it can be inferred that those 3 latent variables play fundamental roles influencing a firm's decision to adopt a TEM.

Although it's the truth when the rate of TEM adoption is $39,3 \%$, which is much lower the rate of TEM non adoption, the authors assume that the actual rate of TEM adoption is 
much lower than the results because of various reasons such as the lack of knowledge and awareness of TEM. The continue to use TEM or not distribution shows that $91.7 \%$ of the TEM adopter will continue to use TEMs, meaning that the future situation of TEMs in Vietnam is quite positive and promising. However, the benefit comparison distribution and plan to adopt or not distribution imply that most Vietnamese firms were still unsuited to consider TEMs as a major transaction channel.

Table 4. The level of relevant of firm's internal environment factors in percentage.

\begin{tabular}{|c|c|c|c|c|c|c|c|}
\hline \multirow[b]{2}{*}{ Code } & \multirow[b]{2}{*}{$\begin{array}{c}\text { Firm's } \\
\text { internal } \\
\text { environment }\end{array}$} & \multicolumn{5}{|c|}{ The level of relevant of factors in percentage } & \multirow[b]{2}{*}{$\begin{array}{l}\text { Average } \\
\text { value }\end{array}$} \\
\hline & & $\begin{array}{c}\text { Not } \\
\text { relevant } \\
1\end{array}$ & $\begin{array}{c}\text { Somewhat } \\
\text { relevant } \\
2\end{array}$ & $\begin{array}{c}\text { Relevant } \\
3\end{array}$ & $\begin{array}{c}\text { Quite } \\
\text { relevant } \\
4\end{array}$ & $\begin{array}{c}\text { Highly } \\
\text { relevant } \\
5\end{array}$ & \\
\hline FIE1 & $\begin{array}{l}\text { Compatibility } \\
\text { for moving } \\
\text { current } \\
\text { transaction to } \\
\text { TEMs }\end{array}$ & 0 & 4.9 & 27.9 & 43.4 & 23.8 & 3.86 \\
\hline FIE2 & $\begin{array}{l}\text { Speed for } \\
\text { completing a } \\
\text { transaction and } \\
\text { exchanging } \\
\text { information }\end{array}$ & 0 & 2.5 & 32.8 & 46.7 & 18.0 & 3.80 \\
\hline FIE3 & $\begin{array}{l}\text { Level of using } \\
\text { IT }\end{array}$ & 0.8 & 4.9 & 33.6 & 42.6 & 18.0 & 3.72 \\
\hline FIE5 & $\begin{array}{l}\text { Employee } \\
\text { willingness, } \\
\text { knowledge, } \\
\text { capability to } \\
\text { accept new IT }\end{array}$ & 0.8 & 5.7 & 35.2 & 39.3 & 18.9 & 3.70 \\
\hline FIE4 & $\begin{array}{l}\text { Top } \\
\text { management } \\
\text { support }\end{array}$ & 0 & 11.5 & 34.4 & 39.3 & 14.8 & 3.57 \\
\hline FIE6 & Seasonality & 1.6 & 14.8 & 33.6 & 31.1 & 18.9 & 3.51 \\
\hline
\end{tabular}

Precondition for the adoption of TEM, not to mention a successful adoption, is the awareness of benefits and drawbacks, as well as, opportunities and threats of TEM adoption.

While considering TEM adoption, firms need to be adequately organized. Considering these factors, organizations will achieve internal readiness for efficient TEM adoption. Research results have shown that all investigated inner-firm factors are important for TEM adoption (see Table 4). The majority of the respondents marked each of the following firm's internal environment factors as relevant and higher to TEM adoption:

- Compatibility for moving current transaction to TEMs $(95.1 \%)$;

- Speed for completing a transaction and exchanging information (97.5\%);

- Level of using IT (94.3\%); 
- Top management support (88.5\%);

- Employee willingness, knowledge, capability to accept new IT (93.4\%);

- Seasonality (83.6\%).

Among 6 factors of firm's internal environment, compatibility for moving current transaction to TEMs, with the average value of 3.86, is the factor that the respondents assumed to affect the decision to adopt TEM the most.

Top management support and seasonality are also two important factors. However, their average values are much different than the author's expectation. The reasons may lie in the fact that top management does not encourage or help the implementation of TEMs in the respondents' companies and seasonality is likely to affect shippers, rather than TSPs as shippers' volumes of goods fluctuated during the time of the year.

Another step in considering TEM adoption investigate clearly about the TEMs in terms of characteristics, trading mechanisms, services offered... By knowing these factors, a firm will be able to choose the optimum TEM for their goals.

Table 5. The level of relevant of firm's attitude towards TEMs factors in percentage.

\begin{tabular}{|c|c|c|c|c|c|c|c|}
\hline \multirow{3}{*}{ Code } & \multirow{3}{*}{$\begin{array}{c}\text { Firm's } \\
\text { attitude } \\
\text { towards } \\
\text { TEMs }\end{array}$} & \multicolumn{5}{|c|}{ The level of relevant of factors in percentage } & \multirow{3}{*}{$\begin{array}{c}\text { Average } \\
\text { value }\end{array}$} \\
\hline & & $\begin{array}{c}\text { Not } \\
\text { relevant }\end{array}$ & $\begin{array}{c}\text { Somewhat } \\
\text { relevant }\end{array}$ & Relevant & $\begin{array}{l}\text { Quite } \\
\text { relevant }\end{array}$ & $\begin{array}{l}\text { Highly } \\
\text { relevant }\end{array}$ & \\
\hline & & 1 & 2 & 3 & 4 & 5 & \\
\hline FATTEM3 & $\begin{array}{l}\text { Potential } \\
\text { benefits } \\
\text { which the } \\
\text { company } \\
\text { can gain } \\
\text { from using } \\
\text { TEM }\end{array}$ & 0 & 2.5 & 19.7 & 49.2 & 28.7 & 4.04 \\
\hline FATTEM6 & $\begin{array}{l}\text { Service } \\
\text { quality and } \\
\text { security } \\
\text { level }\end{array}$ & 0.8 & 4.9 & 32.8 & 36.9 & 24.6 & 3.80 \\
\hline FATTEM2 & $\begin{array}{l}\text { Trading } \\
\text { mechanism }\end{array}$ & 1.6 & 5.7 & 31.1 & 36.1 & 25.4 & 3.78 \\
\hline FATTEM5 & $\begin{array}{l}\text { Level of } \\
\text { ease } \\
\text { using } \\
\text { interface, } \\
\text { functions }\end{array}$ & 0.8 & 4.9 & 32.8 & 44.3 & 17.2 & 3.72 \\
\hline FATTEM4 & $\begin{array}{l}\text { Cost } \\
\text { required } \\
\text { joining a } \\
\text { TEM }\end{array}$ & 0.8 & 9.8 & 30.3 & 40.2 & 18.9 & 3.66 \\
\hline FATTEM1 & $\begin{array}{l}\text { Level of } \\
\text { openness }\end{array}$ & 1.6 & 14.8 & 27.0 & 39.3 & 17.2 & 3.56 \\
\hline
\end{tabular}


Detailed opinions of respondents about firm's attitude towards TEMs factors are described in Table 5 below. It can be seen that with the average of 4.04, potential benefits which the company can gain from using TEM is the factor that the respondents assumed to affect the decision to adopt TEM the most among 6 factors in firm's attitude towards TEMs. It is quite reasonable as what is the point of joining in a TEM without seeing the benefits that it could bring to the firm? The percentages of respondents marking each of the following factors as relevant and higher to TEM adoption are:

- Level of openness (83.6\%);

- Trading mechanism (82.6\%);

- Potential benefits which the company can gain from using TEM (97.5\%);

- Cost required for joining a TEM (89.3\%);

- Level of ease of using interface, functions (94.3\%);

- Service quality and security level (94.3\%).

Level of openness and cost required for joining a TEM are quite lower than the others because respondents may not have many experiences with doing business on TEMs and have low estimations about TEMs.

Table 6. The level of relevant of firm's external environment factors in percentage.

\begin{tabular}{|c|c|c|c|c|c|c|c|}
\hline \multirow{3}{*}{ Code } & \multirow{3}{*}{$\begin{array}{c}\text { Firm's } \\
\text { external } \\
\text { environment }\end{array}$} & \multicolumn{5}{|c|}{ The level of relevant of factors in percentage } & \multirow{3}{*}{$\begin{array}{c}\text { Average } \\
\text { value }\end{array}$} \\
\hline & & $\begin{array}{c}\text { Not } \\
\text { relevan } \\
t\end{array}$ & $\begin{array}{c}\text { Somewhat } \\
\text { relevant }\end{array}$ & Relevant & $\begin{array}{l}\text { Quite } \\
\text { relevant }\end{array}$ & $\begin{array}{l}\text { Highly } \\
\text { relevant }\end{array}$ & \\
\hline & & 1 & 2 & 3 & 4 & 5 & \\
\hline FEE1 & $\begin{array}{l}\text { Trust in } \\
\text { current } \\
\text { business } \\
\text { partners }\end{array}$ & 1.6 & 10.7 & 31.1 & 36.9 & 19.7 & 3.62 \\
\hline FEE5 & $\begin{array}{l}\text { Increase in } \\
\text { demand for } \\
\text { optimization/c } \\
\text { ost reduction }\end{array}$ & 0.8 & 12.3 & 34.4 & 35.2 & 17.2 & 3.56 \\
\hline FEE4 & $\begin{array}{l}\text { Government } \\
\text { support }\end{array}$ & 1.6 & 11.5 & 30.3 & 47.5 & 9.0 & 3.51 \\
\hline FEE2 & $\begin{array}{l}\text { Use of } \\
\text { information } \\
\text { system with } \\
\text { business } \\
\text { partners }\end{array}$ & 2.5 & 19.7 & 44.3 & 23.0 & 10.7 & 3.20 \\
\hline FEE3 & $\begin{array}{l}\text { Key } \\
\text { customers } \\
\text { within supply } \\
\text { chain or } \\
\text { competitors }\end{array}$ & 3.3 & 19.7 & 41.0 & 30.3 & 5.7 & 3.16 \\
\hline
\end{tabular}


The environment in which the firm operates also influences its decision to adopt a TEM or not (see Table 6). Only by knowing these factors will the firms be able to design further necessary steps for efficient use of a TEM in order to improve its competitiveness and achieve competitive advantage in global market. According to Table 6, respondents marked factors as relevant and higher to TEM adoption as follows:

- Trust in current business partners $(87.7 \%)$;

- Use of information system with business partners (77.9\%);

- Key customers within supply chain or competitors $(77 \%)$;

- Government support (86.9\%);

- Increase in demand for optimization/cost reduction (86.9\%).

Among these 5 factors, trust in current business partners is the factor that the respondents assumed to affect the decision to adopt TEM the most in firm's external environment. This result is surprising as the literature indicates that if firms trust current business partners, they are not likely to adopt TEMs. It could be inferred that TEMs will provide a platform not only for firms and new business partners, but also for both firms and its current business partners.

The use of IS with business partners and peer influence are deemed to affect the TEM adoption decision, however, the results are not shown similarly as author's expectation. The use of IS, for example, API (Application Programming Interface), is quite complicated and not all companies utilize this. Also, many companies are doubtful whether these TEMs bring actual benefit or not.

In conclusion, the results of finding the differences between TEM adopters and TEM non-adopters go along with the results of interviews from TEM technology providers as those differences between TEM adopters and TEM non-adopters are the consequences of the misperception or unawareness of people towards TEMs.

Table 7. Hypotheses tested results.

\begin{tabular}{|l|c|c|}
\multicolumn{1}{|c|}{ Hypothesis } & $\begin{array}{c}\text { Sig. (2-tailed) } \\
\text { of t-test }\end{array}$ & Result \\
\hline $\begin{array}{l}\text { H1: There is a significant difference in firm's internal } \\
\text { environment between TEM adopters and TEM non- } \\
\text { adopters. }\end{array}$ & 0.001 & Supported \\
\hline $\begin{array}{l}\text { H2: There is a significant difference in firm's attitude } \\
\text { towards TEMs between TEM adopters and TEM non- } \\
\text { adopters. }\end{array}$ & 0.025 & Supported \\
$\begin{array}{l}\text { H3: There is a significant difference in firm's external } \\
\text { environment between TEM adopters and TEM non- } \\
\text { adopters. }\end{array}$ & 0.000 & Supported \\
\hline
\end{tabular}

(Source: Testing model by running SPSS)

The research model remains the same with 2 groups (TEM adopters and TEM nonadopters), latent variables (firm's internal environment, firm's attitude towards transportation e-marketplaces, and firm's external environment) and seventeen observable variables. The Sig. (2-tailed) value for FIE is 0.001 less than the chosen significance level of 0.05 , which means there is a significant difference in mean of firm's internal environment between TEM 
non-adopters and TEM adopters. H1 is accepted. In like manner, the Sig. (2-tailed) value for FATTEM is 0.025 less than the chosen significance level of 0.05 , meaning that there is a significant difference in mean of firm's attitude towards TEMs between TEM non-adopters and TEM adopters. Hence, $\mathrm{H} 2$ is accepted. The same result also applies to FEE as the Sig. (2tailed) value for FEE is 0.000 less than the chosen significance level of 0.05 . Thus, there is a significant difference in mean of firm's external environment between TEM non-adopters and TEM adopters. Therefore, H3 is accepted. Research hypotheses and their results are presented in Table 7.

Of all the observable variables, potential benefits which the company can gain from using TEM is the factor that respondents assumed to affect the decision to adopt a TEM the most. This is certainly true since people are rational enough to estimate and compare the benefits and the costs when participating in a TEM.

However, indicators including seasonality, top management support, the use of IS with business partners and peer influence do not meet the author's expectation.

In conclusion, based on data collected from user firms of TEMs in Vietnam, this research constructed an independent-samples t-test and found out that there are significant differences in firm's internal environment, firm's attitude towards transportation e-marketplaces, and firm's external environment between TEM adopters and TEM non-adopters. Based on those results, the authors provide some recommendations to issues related to TEM practice as follow:

- Toward the government, especially the Ministry of Industry and Trade, they should be aware of this problem and enact law and regulations on TEM-related issues, starting from updating and clearly stating the definition of TEM, its characteristics, its classification, ... Moreover, TEMs differ from e-commerce in various aspects, especially as the specific goods of TEMs focuses on transportation. As a result, a new regulation applied to TEMs with special support should appear, rather than still using existing regulations of e-commerce management in the TEMs' cases. In addition, the Government should act as an intermediary to assess and monitor the registered TEM's operation based on different fields such as quality, security, openness, ... in order to protect the TEM adopters from negative factors and increase the trust of TEM non-adopters.

- Toward the TEM technology providers, TEM is still a new concept in Vietnam so TEM technology providers should give potential customers opportunities to test and be adapted to new environment such as a one-month free trial, trial workshop, technology conferences, ... then potential customers can experience and figure out the benefits gained from using TEM.

\section{CONCLUSION}

This article enhances the understanding of transportation e-marketplaces in Vietnam. The group of authors hope that it can deepen the knowledge about TEM; identify the characteristics, performances and difficulties of TEMs in Vietnam; find differences between TEM adopters and TEM non-adopters; and formulate recommendations to related parties: the government, the TEM technology providers, and the TEM user firms. However, there are still some certain limitations existing in this study. Firstly, this research considers an entire firm as a unit of analysis instead of individual such as companies' employees or managers. In the future, the authors tend to explore deeper in the activity and behavior of individuals related to 
Transport and Communications Science Journal, Vol. 72, Issue 4 (05/2021), 437-451

TEM. Secondly, this study only focuses on the perspective of the demand side and still does not evaluate on the other sides such as government and not have a comparison between different participants' behavior in TEM. Thirdly, the sample size is still limited in quantity, in method of collecting data and in geographical area (only in Vietnam). In the future, the authors will do more researches to have a brief evaluation in a bigger area such as Southeast Asia with bigger scale.

\section{ACKNOWLEDGE}

This research is funded by University of Transport and Communications (UTC) under grant number T2020-KDN-001. The authors are grateful to the anonymous reviewers on the demand side including shippers and TSPs for their valuable information and suggestions on the study for this paper.

\section{REFERENCES}

[1]. S. Chopra, P. Meindl, Supply Chain Management: Strategy, Planning, and Operation, 6th edn, Pearson, 2007.

[2]. J. Song, A. C. Regan, An Auction Based Collaborative Carrier Network, Transportation Research Record, 43 (2003).

[3]. G. Kuyzu et al., Bid Price Optimization for Truckload Carriers in Simultaneous Transportation Procurement Auctions, Transportation Research Part B: Methodological, 73 (2015) 34-58. https://doi.org/10.1016/j.trb.2014.11.012

[4]. M. S. Janita, F. J. Miranda, The antecedents of client loyalty in business-to-business (B2B) electronic marketplaces, Industrial Marketing Management, 42 (2013) 814-823. https://doi.org/10.1016/j.indmarman.2013.01.006

[5]. I. Lin et al., Electronic Marketplace for Transportation Services: Shipper Considerations, Transportation Research Record Journal of the Transportation Research Board, 1790 (2002) 1-9. https://doi.org/10.3141\%2F1790-01

[6]. A. Rios, Exploring the Use of Freight Exchange E-marketplaces in Sweden: The Perspective of the Transport Service Provider, Lund University, 2018.

[7]. S. Nandiraju, A. Regan, Freight transportation electronic marketplaces: A survey of the industry and exploration of important research issues, Transportation Research Record, 2003.

[8]. J. Y. Bakos, A Strategic Analysis of Electronic Marketplaces, MIS Quarterly, 15 (1991) 295310. https://doi.org/10.2307/249641

[9]. T. J. Strader, M. J. Shaw, Characteristics of electronic markets, Decision Support Systems, 21 (1997) 185-198. https://doi.org/10.1016/S0167-9236(97)00028-6

[10]. W. D. Raisch, The e-Marketplace: Strategies for Success in B2B eCommerce, New York: McGraw-Hill, 2001.

[11]. P. Evangelista, Information and Communication Technology Key Factor in Logistics and Freight Transport, in Ferrara G. and Morvillo A. (eds.), Training in Logistics and Freight Transport Industry, The Experience of the European Project ADAPT-FIT, Ashgate Publishing Ltd, London, UK, 2002, pp. 15-36.

[12]. A. Marasco, Business Models of Transportation Electronic Marketplaces: An Empirical Survey, 
Transport and Communications Science Journal, Vol. 72, Issue 4 (05/2021), 437-451

Annuals of Maritime Studies, 2004.

[13]. Yingli Wang, A. Potter, M. Naim, Electronic marketplaces for tailored logistics, Industrial Management and Data Systems, 107 (2007) 1170-1187. https://doi.org/10.1108/02635570710822804

[14]. Magazine of Transportation, How does market of transportation perform?, 2015. (In Vietnamese). https://www.baogiaothong.vn/san-giao-dich-van-tai-hoat-dong-the-nao-d121324.html, (accessed 20 August 2020)

[15]. R. Angeles, Revisiting the role of Internet-EDI in the current electronic commerce scene, Logistics Information Management, 13 (2000) 45-57. https://doi.org/10.1108/09576050010306396

[16]. G. D. Pires, J. Aisbett, The relationship between technology adoption and strategy in businessto-business markets. The case of e-commerce, Industrial Marketing Management, 32 (2003) 291-300. https://doi.org/10.1016/S0019-8501(02)00237-7

[17]. A. Pucihar, M. Podlogar, E-marketplace adoption success factors: Challenges and opportunities for a small developing country, Electronic Business in Developing Countries: Opportunities and Challenges, Hershey: Idea Group, 2005.

[18]. E. M. Rogers, Diffusion of Innovations, 3rd edn, New York: Free Press, 1983.

[19]. J. Y. L. Thong, C. S. Yap, CEO characteristics, Organizational Characteristics and Information Technology Adoption in Small Business, Omega International Journal of Management Science, 23 (1995) 429-442. https://doi.org/10.1016/0305-0483(95)00017-I

[20]. V. Grover, M. D. Goslar, The Initiation, Adoption, and Implementation of Telecommunications Technologies in U.S. Organization, Journal of Management Information Systems, 10 (1993) 141-164. https://doi.org/10.1080/07421222.1993.11517994

[21]. G. Premkumar, M. Roberts, Adoption of new information technologies in rural small businesses, Omega, 27 (1999) 467-484. https://doi.org/10.1016/S0305-0483(98)00071-1

[22]. W. H. DeLone, Determinants of Success for Computer Usage in Small Business, MIS Quarterly, 12 (1988) 51-61. https://doi.org/10.2307/248803

[23]. R-L. Hsiao, Technology fears: distrust and cultural persistence in electronic marketplace adoption, Journal of Strategic Information Systems, 12 (2003) 69-99. https://doi.org/10.1016/S0963$\underline{8687(03) 00034-9}$

[24]. H. Patel, R. Connolly, Factors influencing Technology Adoption: A Review, Information Management in the Networked Economy: Issues \& Solutions, 2007.

[25]. A. Nair, Emerging internet-enabled auction mechanisms in supply chain, Supply Chain $\begin{array}{llllll}\text { Management: An International Journal, } 10 & \text { (2005) }\end{array}$ https://doi.org/10.1108/13598540510606214

[26]. T. J. Goldsby, J. A. Eckert, Electronic transportation marketplaces: a transaction cost perspective, Industrial Marketing Management, 32 (2003) 187-198. https://doi.org/10.1016/S0019$\underline{8501(02) 00262-6}$

[27]. J. Y. Bakos, Reducing Buyer Search Costs: Implications for Electronic Marketplaces, Management Science, 43 (1997) 1676-1692. https://doi.org/10.1287/mnsc.43.12.1676

[28]. Q. Dai, R. J. Kauffman, Business Models for Internet-Based B2B Electronic Markets, International Journal of Electronic Commerce, $6 \quad$ (2002) 41-72. https://doi.org/10.1080/10864415.2002.11044247

[29]. R. O'Callaghan, R. J. Kaufmann, B. R. Konsynski, Adoption correlates and share effects of electronic data interchange systems in marketing channels, Journal of marketing, 56 (1992) 45-56. 
Transport and Communications Science Journal, Vol. 72, Issue 4 (05/2021), 437-451

https://doi.org/10.2307/1252041

[30]. M. Saunders, P. Lewis, A. Thornhill, Research Methods for Business Students, 6th ed, Pearson Education Limited, 2012.

[31]. J. Biggam, Open up Study Skills: Succeeding with your Master's Dissertation: A step-by-step handbook, Maidenhead, England: McGraw Hill, 2011.

[32]. P. Munn, E. Drever, Using questionaires in small-scale research. A teacher's guide, The Scottish Council for Research in Education, 1990.

[33]. H. P. Fu et al., Factors affecting the adoption of electronic marketplaces: A fuzzy AHP analysis, International Journal of Operations \& Production Management, 26 (2006) 1301-1324. https://doi.org/10.1108/01443570610710560 